\title{
Hand hygiene: knowledge and skill of caregivers in the hematopoietic stem cell transplantation
}

\author{
Higiene das mãos: conhecimento e habilidade de cuidadores no transplante de células-tronco hematopoéticas \\ Higiene de las manos: conocimiento y habilidad de cuidadores en el trasplante de células madre hematopoyéticas
}

Daiane Rubinato Fernandes'

ORCID: 0000-0002-9363-0057

Fernanda Titareli Merizio Martins Braga'

ORCID: 0000-0001-8089-788X

Renata Cristina de Campos Pereira Silveira'

ORCID: 0000-0002-2883-3640

Livia Maria Garbin'

ORCID: 0000-0001-9035-6286

'Universidade de São Paulo, Ribeirão Preto, São Paulo, Brazil.

How to cite this article: Fernandes DR, Braga FTMM, Silveira RCCP, Garbin LM. Hand hygiene: knowledge and skill of caregivers in the hematopoietic stem cell transplantation. Rev Bras Enferm. 2019;72(6):1653-61. doi: http://dx.doi.org/10.1590/0034-7167-2018-0788

Corresponding Author: Livia Maria Garbin E-mail: liviagarbin@usp.br

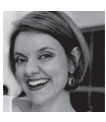

Submission: 10-15-2018

Approval: 04-13-2019

\section{ABSTRACT}

Objective: to identify the knowledge and ability of caregivers on hand hygiene in hematopoietic stem cell transplantation. Method: a prospective cross-sectional study. A questionnaire was used to identify the knowledge and it was observed the hygiene technique performance. Data were collected in two units (autologous and allogeneic transplant). Results: the 37 participants recognized the importance of hand hygiene and $95.5 \%$ related to removal of dirt or infection prevention. $91.9 \%$ stated that it was important to clean their hands with soap and water when entering and leaving the room, and $64.9 \%$ understood that it was necessary to apply alcoholic solution after washing. On average, the caregivers scored 6.16 steps, when demonstrating the washing technique and 3.91 steps in the friction with alcoholic solution. Conclusion: although they recognize the importance of the procedure, there are deficits related to the moment and the correct way of doing it, evidencing the need for strategies aimed at improving this process.

Descriptors: Hand Hygiene; Hand Desinfection; Caregivers; Hematopoietic Stem Cell Transplantation; Bone Marrow Transplantation.

\section{RESUMO}

Objetivo: identificar o conhecimento e habilidade de cuidadores sobre higiene das mãos no transplante de células-tronco hematopoéticas. Método: estudo transversal prospectivo. Utilizou-se questionário para identificar o conhecimento e foi observada a execução da técnica de higienização. Os dados foram coletados em duas unidades (transplante autólogo e alogênico). Resultados: os 37 participantes reconheceram a importância da higienização das mãos e 95,5\% a relacionaram com remoção de sujidade ou prevenção de infecções. $91,9 \%$ citaram ser importante higienizar as mãos com água e sabonete ao entrar e sair do quarto, e 64,9\% entenderam ser necessária a aplicação de solução alcoólica após a lavagem. Em média, os cuidadores acertaram 6,16 passos, ao demonstrarem a técnica de lavagem, e 3,91 passos na fricção com solução alcoólica. Conclusão: embora reconheçam a importância do procedimento, há déficits relacionados aos momentos e à forma correta de realizá-lo, evidenciando a necessidade de estratégias visando à melhoria desse processo.

Descritores: Higiene das Mãos; Desinfecção das Mãos; Cuidadores; Transplante de Células-Tronco Hematopoéticas; Transplante de Medula Óssea.

\section{RESUMEN}

Objetivo: identificar el conocimiento y la habilidad de los cuidadores sobre la higiene de las manos en el trasplante de células madre hematopoyéticas. Método: estudio transversal prospectivo. Se utilizó un cuestionario para identificar el conocimiento y se observó la ejecución de la técnica de higienización. Los datos fueron recolectados en 2 unidades (transplante autólogo y alogénico). Resultados: los 37 participantes reconocieron la importancia de la higienización de las manos y el 95,5\% la relacionaron con remoción de suciedad o prevención de infecciones. 91,9\% citaron ser importantes higienizar las manos con agua y jabón al entrar y salir de la habitación, y el 64,9\% entendieron que era necesaria la aplicación de una solución alcohólica después del lavado. En promedio, los cuidadores acertaron 6,16 pasos, al demostrar la técnica de lavado, y 3,91 pasos en la fricción con solución alcohólica. Conclusión: aunque reconocen la importancia del procedimiento, hay déficit relacionados con el momento y la forma correcta de realizarlo, evidenciando la necesidad de estrategias para la mejora de ese proceso.

Descriptores: Higiene de las Manos; Desinfección de las Manos; Cuidadores; Trasplante de Células Madre Hematopoyéticas; Trasplante de Médula Ósea. 


\section{INTRODUCTION}

Hematopoietic stem cell transplantation (HSCT) consists of the infusion of Hematopoietic Stem Cells (HSC), in order to restore hematopoiesis and the immunological functions of patients with medulary failure, which may be autologous (when HSC are obtained from the patient) or allogeneic (when HSC are collected from a compatible donor) ${ }^{(1)}$.

The HSCT process requires the use of chemotherapy, radiotherapy and other treatments that make patients immunocompromised and more susceptible to infections ${ }^{(1)}$. Moreover, depending on the underlying disease and pre-HSCT treatments, patients may have further impaired immunity ${ }^{(2)}$.

Depending on the HSCT phase, different types of microorganisms may be responsible for infections. In the medullary aplasia phase, due to intense immunosuppression, opportunistic infections are common, as well as those caused by microorganisms of the patient's microbiota ${ }^{(3)}$.

With the aim of preventing infections, the use of antibiotic prophylaxis from the beginning of conditioning is part of the treatment protocol. However, this practice is not enough if specific health care is not incorporated into the patient and the environment. Thus, routines and measures should be incorporated into transplant centers, aiming at the prevention and control of this injury ${ }^{(4)}$.

In this sense, the Centers for Disease Control and Prevention (CDC) Guideline presents cares related to HSCT receptors, the environment, objects, health professionals and visitors; with hand hygiene being recommended as the single most effective measure for the prevention and control of infections ${ }^{(5)}$. This measure is also considered as one of the pillars of patient safety by the World Health Organization (WHO) $)^{(6-7)}$.

Studies on hand hygiene directed to the teaching and practice of health professionals from different areas are commonly described in the literature ${ }^{(8-10)}$. Nonetheless, it is necessary to consider that, in the HSCT, in addition to the work of the health team with this patient, the caregiver plays a fundamental role. Communication with patients and their families, through guidance and knowledge about all aspects of their care, is an important element in patient safety ${ }^{(11)}$.

During the $\mathrm{HSCT}$, the recipient faces numerous challenges, requiring the presence of a caregiver who provides support ${ }^{(12)}$ throughout the hospital treatment period. He must be able to assist the patient in his needs and be a person of reference.

Considering that these caregivers participate in the care offered to the patients, it is imperative that they receive different guidelines and, especially, those related to the measures of prevention and control of infections. In this sense, in order to enable them to acquire knowledge and skills, it is fundamental that the health team, initially, identify their learning needs and promote teaching strategies, regarding the performance of their role ${ }^{(13)}$, since infections related to health care should not be a concern only of patients and health professionals ${ }^{(14)}$.

Thus, initially an integrative review of the literature was proposed, including studies that addressed the subject hand hygiene with caregivers of HSCT recipients, but no studies were developed with this population. However, research conducted with caregivers of other patient populations, and in other care settings, has been published, but there are still few.
A study conducted with kidney transplant recipients and their caregivers, whose objective was to evaluate the need for health education, signaled hand hygiene among the five most misunderstood aspects by the 309 participants ${ }^{(15)}$. On the other hand, results from another research with caregivers pointed out that both the identification of knowledge and the provision of training for caregivers increased hand hygiene compliance ${ }^{(16)}$.

During the clinical experience in HSCT units, it was identified that in many situations the caregivers did not carry out hand hygiene and, in others, they did not perform it correctly. In addition to the lack of research involving this theme and population, it was considered timely to carry out the present study.

\section{OBJECTIVE}

To identify the knowledge and ability of caregivers on hand hygiene in hematopoietic stem cell transplantation.

\section{METHOD}

\section{Ethical aspects}

The project was prepared, according to Resolution 466/12 of the Brazilian Health Board (Conselho Nacional de Saúde) and developed after the approval of the Committee of Ethics in Research of the institution where the study was carried out.

\section{Design, place of study and period}

This is a descriptive cross-sectional study, conducted in two HSCT units of a general hospital; called unit A (intended for autologous HSCT for autoimmune diseases) and unit B (for allogeneic transplantation). Together, the two units have nine beds, six of which are destined to perform transplants.

\section{Population or sample; inclusion and exclusion criteria}

Caregivers of patients hospitalized in these HSCT units were eligible in a period of eight months. It was a convenience sample, with the inclusion criteria: age equal to or greater than 18 years and be accompanying a candidate HSCT patient. Caregivers who were health professionals or students who were following recipients in the post-transplant phase were excluded, or if it was not the first time they accompanied the patient in the referred units. The last criterion was adopted in order to exclude possible biases related to previous exposure or experience of the research subjects.

The data collection was carried out on the second or third day of hospitalization because, on the first day, the patient and caregiver received a great deal of information and guidance about the unit and treatment routines, as well as being absent from the unit for the conduct of examinations. When caregivers were exchanged, data were collected on the second or third day after their arrival at the hospitalization unit.

At the time of data collection, 60 hospitalizations occurred and 14 did not meet the inclusion criteria, of which eight (57.1\%) were absent on the second or third day of hospitalization and six (42.9\%) were hospitalization of HSC donors. Of the remaining 46, there were 
13 exclusions, three (23\%) because they were post-transplant readmissions. Regarding the caregivers, five (38.5\%) were professionals in the health area and the other five (38.5\%) had already accompanied the patient in these units in previous hospitalizations.

Thus, data were collected from 37 caregivers of 33 patients, since in two situations, a relay was performed, culminating in the collection of data from two caregivers, and in another situation, the collection with three caregivers of the same patient.

\section{Study protocol}

In order to collect data, a specific instrument was built for this population, based on the recommendations of the CDC, Brazilian Health Regulatory Agency (ANVISA - Agência Nacional de Vigilância Sanitária) $)^{(6)}$ and WHO guidelines ${ }^{(7)}$ for hand hygiene and prevention of infections. It was used language of easy understanding, being organized according to the following items: 1) demographic characterization data (gender, age, relationship with the patient, occupation and educational level); 2) reason for patient hospitalization; 3) semi-structured questionnaire about hand hygiene knowledge with emphasis on the HSCT situation and how this content was administered (patient follow-up and exposure to such knowledge in previous situations, perception about the importance of hand hygiene, current hospitalization - professional who carried out the orientation, form of orientation, which was explained; what products can be used for hygiene, in which situations related to the day-to-day life in the hospitalization unit, water and liquid soap or alcohol solution indicated, and which people are in the hospital environment which he believes should clean their hands); 4) checklist, in which, in order to enable the structured evaluation by the observer, the technique of hygiene with water and liquid soap was divided in 10 steps; and in seven steps, in the case of hygiene with alcoholic solution. Each of the steps was classified as correct, incorrect or not performed. There was also a space for annotation of possible observations related to the procedure.

The instrument was validated as to its presentation (how the items that made up the instrument were organized) and content (check if the items are comprehensible and sufficient to achieve the proposed goal) by five experts, four nurses and one physician. All of them had experience in the area of HSCT and/or prevention and control of infections. All had Masters and/or Doctorates completed or in progress, with scientific publications related to the subject.

The objective of the study was explained and the data collection instrument was delivered to the experts who had a period of two weeks for its evaluation. Suggestions were made on the instrument itself. Regarding content, the notes were related to the questions whose objective was to identify in which situations the participant considered it important to sanitize the hands. These questions were initially idealized as multiple-choice questions, and it was suggested by the experts that they should be dissertations - called free answer questions ${ }^{(17)}$, in order to prevent answers from being induced. It was also suggested the inclusion of questions related to the use of alcoholic solution (moments in which it can be used). In relation to the presentation of the instrument, it was directed the increase of the space destined to the answers. After all the suggestions were accepted, the instrument was considered adequate to reach the objective.
In the study units, usually the guidelines for hand hygiene consist of an explanation about the procedure and its importance, situations in which hygiene should be performed and delivery of printed information material. In addition, there are posters with step-by-step illustrations of the procedure in front of all sinks used for this purpose.

To identify hospitalizations or exchange caregivers, visits or daily telephone calls were made to the units. After explaining the study and inviting the eligible caregivers and those who agreed to participate, they signed the Free and Informed Consent Form in two copies.

Questions to identify the knowledge were made in the way they were written, so that there was no influence on the answer. In case of doubts, they were repeated. The participant was then asked to demonstrate hand hygiene with water and liquid soap and with alcoholic solution (in this case, 70\% alcohol in gel). At that time, it was again emphasized to the same, the purpose of the study and the importance of performing the procedure the way it learned and knew how to do. The interview was performed inside the ward (being individual in these units) and the demonstration of hand hygiene in the existing sink in the corridor, next to the door of each ward. All data were collected by a single researcher in order to minimize biases both in the transcribed answers to the instrument and in the observation of the accomplishment of each step of the procedure performed by caregivers.

\section{Analysis of results and statistics}

Data were typed in an Excel for Windows 2007 spreadsheet program. Double-typing was performed and after the inconsistencies were corrected, they were exported to SPSS version 25. Descriptive statistics were used, the nominal variables being presented by means of absolute frequency and percentage, and the numerical variables by mean, Standard Deviation and minimum and maximum values. The comparison of the number of correct steps in the demonstration of the technique of hygiene with water and liquid soap and with alcoholic solution was performed for the variables: sex (female and male), schooling level of the caregivers (complete high school, or complete or incomplete higher education), relationship with the patient, (mother or others) and hospitalization unit (Unit A and Unit B). The non-parametric Mann-Whitney test was used, being adopted $p<0.05$. This test was chosen because it is suitable for small sample analysis and does not require assumption about data distribution. For the analysis of the data from the free answer questions, standard answers ${ }^{(17)}$ were elaborated according to the recommendations of the literature ${ }^{(5-7)}$, experience of researchers in caring for this population and printed material with guidelines on the routines of the units.

\section{RESULTS}

As shown in Table 1, the majority of participants were female, with a mean age of 43.9 years (range from 22 to 67 years). A large proportion had completed high school $(n=30,81.1 \%)$ and nine (24.3\%) participants reported that their main occupation was home. Regarding the relationship with the patient, in thirteen (35.2\%) situations the caregivers were the mothers.

Regarding the patients' reasons for hospitalization, they were divided into: allogeneic HSCT ( $n=12 ; 36.4 \%$ ) or autologous 
( $n=10,30.3 \%$ ), autologous ( $n=09 ; 27.3 \%$ ) or allogeneic pretransplantation exams $(n=01 ; 3 \%)$ and mobilization for the collection of autologous HSC $(n=01 ; 3 \%)$.

Table 1 - Characterization of caregivers in hematopoietic stem cell transplantation units ( $\mathrm{N}=37$ ), Ribeirão Preto, São Paulo, Brazil, 2017

\begin{tabular}{lc}
\hline Variables & $\mathbf{n}(\%)$ \\
\hline Gender & \\
Female & $25(67.6)$ \\
Male & $12(32.4)$ \\
Schooling level & \\
Complete high school & $15(40.6)$ \\
Complete higher education & $12(32.4)$ \\
Incomplete high school & $04(10.8)$ \\
Incomplete elementary and middle school & $03(8.1)$ \\
Incomplete higher education & $03(8.1)$ \\
Occupation & \\
Home & $09(24.3)$ \\
Business woman (man) & $05(13.5)$ \\
Saleswoman (man) & $05(13.5)$ \\
Lawyer & $02(5.4)$ \\
Others & $16(43.3)$ \\
Relationship with patient & \\
Mother & $13(35.2)$ \\
Sister (brother) & $06(16.2)$ \\
Spouse & $06(16.2)$ \\
Father & $03(8.1)$ \\
Others & $09(24.3)$ \\
\hline
\end{tabular}

Participants were asked if they thought it important to hand hygiene and everyone said yes. In addition, they reported believing that all persons who enter the rooms or have contact with patients should perform the procedure.

When asked the objective of hand hygiene, 35 (95.5\%) associated the procedure with the prevention of transmission of microorganisms, infections or removal of dirt.

When the caregivers were asked to report how they received the guidelines at the beginning of the follow-up of the patients in the unit and who was the professional responsible for the guidelines, $30(81.1 \%)$ reported having received verbal information, six (16.2\%), verbal and written information. One (2.7\%) reported not having received information, and in 32 (86.5\%) cases, the orientation was made by the nurse in the sector and, in the others, by nursing auxiliaries or technicians.

Table 2 - Orientation on hand hygiene given to caregivers ( $N=37)$, Ribeirão Preto, São Paulo, Brazil, 2017

\begin{tabular}{|c|c|}
\hline Orientations reported & n (\%) \\
\hline $\begin{array}{l}\text { It was explained that I should wash my hands when } \\
\text { entering and leaving the room }\end{array}$ & $26(70.3)$ \\
\hline $\begin{array}{l}\text { It was reported that it is the hospital norm that I should } \\
\text { always wash my hands }\end{array}$ & 05 (13.5) \\
\hline $\begin{array}{l}\text { It was said that I should wash my hands and apply the } \\
\text { alcohol in gel }\end{array}$ & $03(8.1)$ \\
\hline $\begin{array}{l}\text { It was explained how I should wash my hands and in } \\
\text { what moments }\end{array}$ & $01(2.7)$ \\
\hline $\begin{array}{l}\text { It was explained how I should wash my hands } \\
\text { (demonstration of technique) }\end{array}$ & $01(2.7)$ \\
\hline I did not receive any information & $01(2.7)$ \\
\hline
\end{tabular}

In Table 2, are described the items that the caregivers reported that were addressed during orientation. 26 (70.3\%) participants responded that they were informed that they should hygienize their hands on entering and leaving the room. The demonstration of the technique or the explanation of how hygiene should be done were mentioned by only two (5.4\%) caregivers.

When asked to report which products they knew they could use to sanitize their hands, 31 (83.8\%) participants mentioned water, liquid soap and alcohol solution; five (13.5\%) cited water and liquid soap, and one (2.7\%), besides water, soap and alcoholic solution, reported using hydrogen peroxide, believing that it would be efficient for the removal of microorganisms.

Table 3 lists the situations in which caregivers reported considering it important to clean their hands with water, liquid soap and alcohol solution. Regarding the technique with water and liquid soap, 34 (91.9\%) mentioned that they consider it important to perform hygiene every time they enter and leave the room, while other situations in which hygiene should be performed, such as during meals times, are cited by a small number of caregivers.

As for the situations in which alcoholic solution can be used, 24 (64.9\%) caregivers believe in the need to use it after washing with water and liquid soap. On the other hand, one (2.7\%) caregiver mentioned that he did not feel it necessary to clean the hands with alcoholic solution (Table 3 ).

Table 3 - Situations in which it is important to clean the hands, according to the caregivers' understanding ( $N=37$ ), Ribeirão Preto, São Paulo, Brazil, 2017

\begin{tabular}{lc}
\hline Situations for hand hygiene & $\mathbf{n}(\%)^{*}$ \\
\hline Water and liquid soap & $34(91.9)$ \\
On entering and leaving the room & $05(13.5)$ \\
When to help the patient to go to the bathroom & $05(13.5)$ \\
When touching objects & $04(10.8)$ \\
When assisting the patient with meals & \\
Alcoholic solution & $24(64.9)$ \\
After you've washed your hands & $08(21.6)$ \\
When touching objects & $02(5.4)$ \\
When you do not want to wash your hands & $01(2.7)$ \\
When you touch the doorknob & $01(2.7)$ \\
When you leave the room and do not touch anything & $01(2.7)$ \\
I do not think it necessary & \\
\hline Note: *Sum of percentages above 100\% because some subjects cited more than one situation
\end{tabular}

Table 4 shows the steps of hand hygiene performed by the caregivers with water and liquid soap, and the frequency of correct, incorrect and non-performance of each of them.

It is noteworthy that in $22(59.5 \%)$ cases, participants were considered to have incorrectly wet their hands because they first applied the soap and then wet their hands or did not wet all the regions of the hands. Rubbing the palms was the most successful ( $n=35,94.6 \%)$, whereas $29(78.4 \%)$ caregivers did not sanitize the digital nails and pulps (Table 4).

Table 5 shows the hand hygiene steps performed by the caregivers with alcoholic solution, and the most frequently performed step was the application of the solution to all surfaces of the hands.

As in hygiene with water and liquid soap, the palms were the region of the hands correctly rubbed with alcoholic solution by the majority ( $n=33,91.7 \%)$, while $28(77.8 \%)$ subjects did not rub the nails and pulps (Table 5). 
Table 4 - Hand hygiene technique steps with water and liquid soap, performed by the caregivers ( $N=37)$, Ribeirão Preto, São Paulo, Brazil, 2017

\begin{tabular}{|c|c|c|c|}
\hline Technique steps & $\begin{array}{l}\text { Correct } \\
\text { n (\%) }\end{array}$ & $\begin{array}{l}\text { Incorrect } \\
\text { n (\%) }\end{array}$ & $\begin{array}{l}\text { Did not } \\
\text { perform it } \\
n(\%)\end{array}$ \\
\hline 1. Got the hands wet & $14(37.8)$ & $22(59.5)$ & $01(2.7)$ \\
\hline $\begin{array}{l}\text { 2. Applied alcoholic solution on all } \\
\text { surfaces of the hands }\end{array}$ & $34(91.9)$ & $03(8.1)$ & - \\
\hline $\begin{array}{l}\text { 3. Rubbed the palms of the hands } \\
\text { and rubbed them together }\end{array}$ & $35(94.6)$ & - & $02(5.4)$ \\
\hline $\begin{array}{l}\text { 4. Rubbed the palm of the right } \\
\text { hand against the back of the left } \\
\text { hand, interlacing the fingers, and } \\
\text { vice versa }\end{array}$ & $23(62.2)$ & $04(10.8)$ & $10(27.0)$ \\
\hline $\begin{array}{l}\text { 5. Interlaced the fingers and } \\
\text { rubbed the interdigital spaces }\end{array}$ & $15(40.5)$ & $01(2.7)$ & $21(56.8)$ \\
\hline $\begin{array}{l}\text { 6. Rubbed the back of the fingers } \\
\text { of the right hand with the palm of } \\
\text { the left hand and vice versa }\end{array}$ & $14(37.8)$ & $01(2.7)$ & $22(59.5)$ \\
\hline $\begin{array}{l}\text { 7. Rubbed in rotation movement } \\
\text { the left thumb with the right palm } \\
\text { and vice versa }\end{array}$ & $13(35.1)$ & - & $24(64.9)$ \\
\hline $\begin{array}{l}\text { 8. Rubbed in rotation movement } \\
\text { the digital nails and pulps of the } \\
\text { right hand in the palm of the left } \\
\text { hand and vice versa }\end{array}$ & $08(21.6)$ & - & $29(78.4)$ \\
\hline 9. Dried the hands & $36(97.3)$ & $01(2.7)$ & - \\
\hline 10. Dried the hands with paper towel & $36(97.3)$ & - & $01(2.7)$ \\
\hline
\end{tabular}

Table 5 - Hand hygiene technique steps with alcoholic solution performed by the caregivers $\left(n=36^{*}\right)$, Ribeirão Preto, São Paulo, Brazil, 2017

\begin{tabular}{lccc}
\hline Technique steps & $\begin{array}{c}\text { Correct } \\
\mathbf{n}(\%)\end{array}$ & $\begin{array}{c}\text { Incorrect } \\
\mathbf{n}(\%)\end{array}$ & $\begin{array}{c}\text { Did not } \\
\text { perform it } \\
\mathbf{n}(\%)\end{array}$ \\
\hline $\begin{array}{l}\text { 1. Applied alcoholic solution on } \\
\text { all surfaces of the hands }\end{array}$ & $35(97.2)$ & $01(2.8)$ & - \\
$\begin{array}{l}\text { 2. Rubbed the palms of the hands } \\
\text { and rubbed them together }\end{array}$ & $33(91.7)$ & $02(5.6)$ & $01(2.8)$ \\
$\begin{array}{l}\text { 3. Rubbed the palm of the right } \\
\text { hand against the back of the left } \\
\text { hand, interlacing the fingers, and } \\
\text { vice versa }\end{array}$ & $21(58.3)$ & $04(11.1)$ & $11(30.6)$ \\
$\begin{array}{l}\text { 4. Interlaced the fingers and } \\
\text { rubbed the interdigital spaces }\end{array}$ & $15(41.7)$ & $01(2.8)$ & $20(55.6)$ \\
$\begin{array}{l}\text { 5. Rubbed the back of the fingers } \\
\text { of the right hand with the palm of } \\
\text { the left hand and vice versa }\end{array}$ & $13(36.1)$ & - & $23(63.9)$ \\
$\begin{array}{l}\text { 6. Rubbed in rotation movement } \\
\text { the left thumb with the right } \\
\text { palm and vice versa }\end{array}$ & $16(44.4)$ & - & $20(55.6)$ \\
$\begin{array}{l}\text { 7. Rubbed in rotation movement } \\
\text { the digital nails and pulps of the } \\
\text { right hand in the palm of the left } \\
\text { hand and vice versa }\end{array}$ & $08(22.2)$ & - & $28(77.8)$ \\
\hline
\end{tabular}

Note: *One participant did not demonstrate hygiene with alcoholic solution, because he reported not knowing this product.

Each participant achieved, on average, 6.16 steps in hand hygiene with water and liquid soap (variation of two to 10 hits, $\mathrm{SD}=2.11$ ) and 3.91 steps in hand hygiene with alcoholic solution (variation of one to seven hits, SD =1.84).
Considering that the guidelines and/or the apprehension of this knowledge could have occurred differently among the caregivers of the two hospitalization units, it was made the comparison of the number of correct answers between them both in the hygiene with water and liquid soap and in the use of alcoholic solution, not having been evidenced statistically significant differences ( $p$ $=0.478$ and $p=0.916$, respectively). When considering gender, schooling level and caregiver relationship with the patient, no differences were also found ( $p>0.05$ in all situations analyzed).

\section{DISCUSSION}

Hand hygiene is recognized worldwide as the most important and cost-effective way to reduce infection rates in the hospital environment ${ }^{(7)}$. The literature points out the importance of this practice. Specialists bet on the standardization of the procedure as a way to guarantee its effectiveness ${ }^{(18)}$. However, this aspect is emphasized in the HSCT, since the infections are most responsible for the failure of the procedure ${ }^{(3)}$.

As identified in this study, the results of a systematic review indicated that most parents of hospitalized children were not aware of indications for hand hygiene but recognized it as an important tool for the prevention of infections ${ }^{(19)}$. Recognition of the importance of this procedure in the hospital environment is also reinforced in a study in which it was pointed out that the education of family members, caregivers and visitors is fundamental in the process of infection prevention and control, since this population is able to identify hand hygiene, especially in this environment ${ }^{(20)}$.

When asked about what had been explained and/or demonstrated, according to the standard answer elaborated, the main aspects were the importance and the reason for hand hygiene, the moments in which it should be performed, and the explanation and/or demonstration of the technique. These are indispensable items related to the procedure and are contemplated both in the planning of teaching in the units and in the printed information material that is delivered to the caregivers.

Nonetheless, most just reminded that they should perform the procedure on entering and leaving the room. Only one mentioned the moments for the accomplishment and the steps of the technique, leading to the reflection in relation to the aspects that could have compromised the understanding and/or apprehension of this information, such as the large amount of information or the way the guidelines are made, although this is not the focus of the present study. It is described in the literature that people are able to store much more information when they see and hear it, besides the repetition of information being cited as an important way of memorizing ${ }^{(21)}$, leading to the reflection of two main points. The first is the need to strengthen the guidelines throughout the process, since they are usually done on the day of hospitalization, when other information is provided and may compromise their understanding and apprehension. The second concerns the need to rethink the teaching and learning strategies currently employed, in order to improve understanding and memorization of content.

Hand hygiene in the hospital environment can be performed with alcoholic solution or with water and liquid soap, the latter 
being the only possibility in some specific situations. If the alcoholic solution is used in gel, it should have a final concentration of $70 \%$. Simple hygiene with liquid soap and water is intended to remove microorganisms that colonize the superficial layers of the skin, as well as sweat, oil and dead cells, removing dirt that is conducive to the permanence and proliferation of microorganisms. On the other hand, the alcoholic solution does not provide dirt removal, with the purpose of reducing the microbial load and replacing the hygiene with soap and water when the hands do not have visible dirt, WHO recommends it as the main form of routine hand hygiene in health services ${ }^{(7,22)}$.

It should be emphasized that this recommendation is aimed at health professionals. However, because there are no specific recommendations to caregivers in the hospital environment and because they are involved in patient care, this measure ends up being applied to them. Although the majority of participants were in compliance with current recommendations regarding the hospital environment when reporting the possible use of alcoholic solution or water and liquid soap for hand hygiene, five $(13.5 \%)$ did not mention the possibility of using alcohol solution. These data can be both the reflection of the routine in the domestic environment, in which there is no restricted indication to the use of alcoholic solution, as well as of the own form of orientation by the professional. According to the results of a recent study carried out with 150 physicians and members of the nursing team, they showed a preference for hand hygiene with water and liquid soap (78\%) instead of rubbing with alcohol solution $(22 \%)^{(23)}$.

Due to the availability of only materials directed to health professionals in the hospital environment ${ }^{(5,22)}$, in regard to the moments in which hands hygiene should be performed, standard answers were elaborated, considering the existing recommendations, routine activities in HSCT centers and the caregivers' performance in this context.

In relation to the hygiene with water and liquid soap, the moments mentioned for its accomplishment were when entering and leaving the room, helping the patient to go to the bathroom, touching objects and assisting the patient at meals. It was hoped that the need for hygiene would also be cited when hands are visibly soiled; after going to the bathroom and assisting the patient in his hygiene needs; before and after meals of the patient and caregiver; before touching devices, such as probes and catheters; and handling objects or touching surfaces in areas outside the room. Although in some situations mentioned above the use of alcoholic solution is indicated and sufficient, routinely, in the domestic environment, it is not available and is not usually used by these people. Since there is no contraindication for washing in any of the mentioned situations, this form of hygiene was considered adequate.

As for the alcohol solution, $64 \%$ mentioned the need to use it after washing with soap and water and at other times, such as touching and handling objects, when you do not want to wash your hands, and when you leave the room and do not touch anything. According to the standard answer, they were expected to mention the same situations described for washing with soap and water as long as there was no visible dirt. Although no parameters have been identified in the literature for comparison, these data point out that it is difficult for caregivers to identify the situations in which the procedure is necessary, and there is an erroneous understanding that washing needs to be preceded by rubbing with alcohol solution.

Although not predicted, they were questioned about this aspect and reported believing that the use of alcoholic solution after washing would increase hand cleaning.

Finally, the technique of hand hygiene was evaluated by its demonstration. It was identified studies in which the evaluation was carried out with professionals ${ }^{(24-25)}$ and students of the health area ${ }^{(26-27)}$, as well as papers that address the activities and practices carried out by family caregivers and their perception related to the transmission and prevention of infectious diseases ${ }^{(28)}$. However, no studies were identified that assessed the performance of the technique by caregivers.

Hygiene with soap and water was divided into 10 steps and with alcoholic solution in seven steps, and the average number of steps performed correctly was 6.16 and 3.91, respectively. No criteria were found in the literature for judging the number of steps required for the technique to be considered adequate among caregivers, but it is emphasized that only 13 (35.1\%) correctly performed at least $80 \%$ of the steps in the hygiene with water and liquid soap. 11 (29.7\%) reached this percentage in the hygienic solution with alcohol solution.

In both demonstrations, the steps performed correctly by the majority of the participants were product application and palm rubbing. On the other hand, the digital nails and pulps, followed by the thumbs and back of the fingers, were the regions less contemplated, corroborating with a study carried out with domestic caregivers, in which palms of the hands rubbing was performed by all the participants of the study, whereas the friction of the nails was the step that obtained fewer hits, being contemplated in only $27 \%$ of the observations. The authors also mentioned that the way hand hygiene is performed influences considerably the achievement of positive results related to the procedure, and reinforced the importance of standardization of the technique, even outside the hospital environment ${ }^{(29)}$.

Considering that the guidelines were carried out by different teams in both units, it was suggested that the performance of caregivers may be different. However, no differences were found when comparing the two groups of caregivers in relation to the number of steps performed correctly. Likewise, it was not possible to identify the relationship between the level of schooling, the caregiver's relationship with the patient, and their influence in this process.

All participants attached great importance to hand hygiene. However, shortcomings were observed in the technique performance, as well as in the work performed with relatives in a public hospital in Bangladesh, which showed that, in fact, there is a concern related to the transmission of infections by the caregivers, however, hand hygiene compliance is low and may be indicative of the need for educational strategies aimed at these populations ${ }^{(28)}$.

Despite the difficulty in identifying studies that evaluate both the knowledge of the caregivers regarding hand hygiene and technique performance, it was possible to identify works that evidenced the necessity of implantation of educational strategies directed to this population. It was also necessary, as pointed out 
in the literature, the insertion and empowerment of patients and caregivers in the caring process ${ }^{(30)}$.

In this sense, a study carried out with caregivers of children revealed that hygiene practices, including hand hygiene, mainly in food preparation, increased after training of this population, as did the incidence of diarrhea in children from $45 \%$ to $8.6 \%$. The authors concluded that the identification of knowledge and the training of caregivers contributed to increase appropriate hygiene practices compliance, among them, hand hygiene ${ }^{(16)}$.

Results from another study pointed out that caregivers may have been responsible for an infectious outbreak caused by multidrug-resistant bacteria in a hospital unit, due to noncompliance with the hand hygiene protocol; and the outbreak was controlled after an educational intervention on the protocol was performed with caregivers ${ }^{(31)}$.

When evaluating the implementation of the multimodal strategy for improving hand hygiene proposed by the WHO, in an Italian health institution, authors found that $55 \%$ of health units provided information to patients and only $15 \%$ actively involved patients and their families in the education process. It recognizes these results as critical, since the multimodal strategy includes this population precisely because it recognizes its importance in the context of improved hand hygiene ${ }^{(32)}$.

Thus, the lack of knowledge and difficulties in performing the technique, observed in the present study, which may be related to the teaching-learning strategies used and the factors inherent to each individual and situational, such as the cognitive level, the amount of information, hospitalization-related stress, and fear of the unknown; reinforce the need for this population to be targeted by health professionals in the implementation of educational strategies aimed at prevention and control of infections, as pointed out in the literature.

\section{Study limitations}

It is mentioned the fact that data were collected in a single health institution as limitation for the performance of this study.

The small number of subjects investigated may influence the generalization of results. However, this number can be justified by transplantation requiring prolonged hospitalizations and also by the hospital have only six beds for this intervention. Also, it is important to note that the number of HSCT performed in Brazil annually is reduced. Data from the Brazilian Association of Organ Transplantation show that, in 2017, 2794 procedures were performed in the country ${ }^{(33)}$.

Another possible limitation concerns the Hawthorne effect in demonstrating the hygiene technique by caregivers, leading to a possible observation bias. However, in recognition of the importance of the caregivers' procedure and its impact on patient care, and because they were instructed to perform the procedure in the way they were taught, not in the way they did, that this possible bias has been minimized.

Finally, it was difficult to compare with literature data, due to the absence of studies that have approached this theme. Despite the existence of such limitations, the data obtained allow us to reflect on the current setting.

\section{Contributions to the field of Nursing}

Considering that there were no studies in the literature dealing with "hand hygiene", specifically with caregivers of HSCT recipients, it is believed that the presented results can contribute to subsidize the densification of studies on this subject. Considering the role of the caregiver in this setting, there is a need for a structured look for this population that through its performance also needs training and information regarding the measures applicable to it regarding the infections prevention and control ${ }^{(28)}$.

\section{CONCLUSION}

In this study, it was possible to identify the contradiction between the perception that the caregivers present regarding the importance of hand hygiene as an important measure for the prevention and control of infections, and the knowledge they demonstrate when questioned and the skill in the development of the technique.

These data reflect the need to deepen the identification of the needs of this population, and consequent planning and implementation of health education strategies capable of addressing these deficiencies, enabling the caregiver to become an active and conscious part of the process, becoming a partner in patient safety and harm prevention, as proposed by the WHO.

\section{REFERENCES}

1. Freitas TF, Souza SR, Soria DAC. A resiliência na trajetória de clientes no pós-transplante de células-tronco hematopoiéticas. Rev Cubana Enferm [Internet]. 2018 [cited 2019 Mar 14];34(2). Available from: http://revenfermeria.sld.cu/index.php/enf/article/view/1599/351

2. Garnica M, Machado C, Cappellano P, Carvalho VVH, Nicolato A, Cunha CA, et al. Management of infectious complications after hematopoietic stem cell transplant. Rev Bras Hematol Hemoter. 2010;32(Suppl 1):140-62. doi: 10.1590/S1516-84842010005000026

3. Zavadil ETC, Mantovani MF, Cruz EDA. Representação do enfermeiro sobre infecções submetidos a transplante de células-tronco hematopoiéticas. Esc Anna Nery. 2012;16(3):583-7. doi: 10.1590/S1414-81452012000300022

4. Balletto E, Mikulska M. Bacterial infections in hematopoietic stem cell transplant recipients. Mediterr J Hematol Infect Dis. 2015;7(1):e2015045. doi: 10.1097/MOH.0000000000000088

5. Sullivan KM, Dykewicks CA, Longworth DL, Boeckh M, Baden LR, Rubin RH. et al. Preventing opportunistic infections after hematopoietic stem cell transplantation: the Centers for Disease Control and Prevention, Infectious Diseases Society of America, and American Society for Blood and Marrow Transplantation Practice Guidelines and Beyond. Hematology Am Soc Hematol Educ Program. 2001;1:392-421. doi: 
6. Agência Nacional de Vigilância Sanitária (ANVISA). Indicadores nacionais de infecções relacionadas à assistência à saúde. Brasília; 2010.

7. World Health Organization (WHO). WHO guidelines on hand hygiene in health care. First global patient safety challenge. Clean care is safer care [Internet]. Geneva:WHO; 2009 [cited 2019 Mar 14]. Available from: http://apps.who.int/iris/bitstream/10665/44102/1/9789241597906_eng.pdf

8. Zottele C, Magnago TSBS, Dullius AIS, Kolankiewicz ACB, Dal Ongaro J. Hand hygiene compliance of healthcare professionals in an emergency department. Rev Esc Enferm USP. 2017;51:e03242. doi: 10.1590/s1980-220x2016027303242

9. Trannin KPP, Campanharo CRV, Lopes MCBT, Okuno MFP, Batista REA. Adherence to hand hygiene: intervention and assessment. Cogitare Enferm. 2016;21(2):1-7. doi: 10.5380/ce.v21i2

10. Sadule-Rios N, Aguilera G. Nurses' perceptions of reasons for persistent low rates in hand hygiene compliance. Intensive Crit Care Nurs. 2017;42:17-21. doi: 10.1016/j.iccn.2017.02.005

11. Agência Nacional de Vigilância Sanitária (ANVISA). Assistência Segura: Uma Reflexão Teórica Aplicada a Prática [Internet]. Brasília: ANVISA; 2017[cited 2019 Mar 14]. Available from: http://portal.anvisa.gov.br/documents/33852/3507912/Caderno+1+-+Assistência+Segura+-+Um a+Reflexão+Teórica+Aplicada+à+Prática/97881798-cea0-4974-9d9b-077528ea1573

12. Bevans M, Wehrlen L, Castro K, Prince P, Shelburne N, Soeken K, et al. A problem-solving education intervention in caregivers and patients during allogeneic hematopoietic stem cell transplantation. J Health Psychol. 2014;19(5):602-17. doi: 10.1177/1359105313475902

13. Metoyer LJ. Education of hematopoietic stem cell transplant caregivers in preparation for their role [Internet]. J Adv Pract Oncol. 2013 [cited 2019 Mar 14];4(6):432-7. Available from: https://www.ncbi.nlm.nih.gov/pmc/articles/PMC4093455/

14. Islam MS, Luby SP, Sultana R, Rimi NA, Zaman RU, Uddin M, et al. Family caregivers in public tertiary care hospitals in Bangladesh: risks and opportunities for infection control. Am J Infect Control. 2014;42(3):305-10. doi: 10.1016/j.ajic.2013.09.012

15. Xie J, Ming Y, Ding S, Wu X, Liu J, Liu L, et al. Rising need for health education among renal transplant patients and caregiving competence in care providers. Prog Transplant. 2017;27(2):180-6. doi: 10.1177/1526924817699962

16. Geresomo NC, Mbuthia EK, Matofari JW, Mwangwela AM. Targeting caregivers with context specific behavior change training increased uptake of recommended hygiene practices during food preparation and complementary feeding in Dedza district of Central Malawi. Ecol Food Nutr. 2018;57(4):301-13. doi: 10.1080/03670244.2018.1492379

17. Vianna HM. Testes em educação. $2^{a}$ ed. São Paulo: Ibrasa; 1976.

18. Škodová M, Gimeno-Benítez A, Martínez-Redondo E, Morán-Cortés JF, Jiménez-Romano R, Gimeno-Ortiz A. Hand hygiene technique quality evaluation in nursing and medicine students of two academic courses. Rev Latino-Am Enfermagem. 2015;23(4):708-17. doi: 10.1590/0104-1169.0459.2607

19. Bellissimo-Rodrigues F, Pires D, Zingg W, Pittet D. Role of parents in the promotion of hand hygiene in the paediatric setting: a systematic literature review. J Hosp Infect. 2016;93(2):159-63. doi: 10.1016/j.jhin.2016.02.001

20. Clark J, Henk JK, Crandall PG, Crandall MA, O'Bryan CA. An observational study of handwashing compliance in a child care facility. Am J Infect Control. 2016;44(12):1469-74. doi: 10.1016/j.ajic.2016.08.006

21. Oliveira KL, Boruchovitch E, Santos AAA. Estratégias de aprendizagem e desempenho acadêmico: evidências de validade. Psic Teor Pesq 2009;25(4):531-6. doi: 10.1590/S0102-37722009000400008

22. Ministério da Saúde (BR). Agência Nacional de Vigilância Sanitária (ANVISA). Protocolo para a prática de higiene das mãos em serviços de saúde [Internet]. Brasília: ANVISA; 2013 [cited 2019 Mar 14]. Available from: https://www20.anvisa.gov.br/segurancadopaciente/index.php/ publicacoes/item/higiene-das-maos

23. Oliveira AC, Pinto AS. Patient participation in hand hygiene among health professionals. Rev Bras Enferm [Internet]. 2018;71(2):259-64. doi: 10.1590/0034-7167-2016-0124

24. Santos TCR, Roseira CE, Piai-Morais TH, Figueiredo RM. Hand hygiene in hospital environments: use of conformity indicators. Rev Gaúcha Enferm. 2014;35(1):70-7. doi: 10.1590/1983-1447.2014.01.40930

25. Nicholson AM, Tennant IA, Martin AC, Ehikhametalor K, Reynolds G, Thoms-Rodriguez CA, et al. Hand hygiene compliance by health care workers at a teaching hospital, Kingston, Jamaica. J Infect Dev Ctries. 2016;10(10):1088-92. doi: 10.3855/jidc.7083

26. Martinez J, Roseira CE, Figueiredo RM, Passos IPBD. Higienização das mãos: conhecimento dos estudantes. Cienc Cuid Saúde. 2014;13(3):455-63. doi: 10.4025/cienccuidsaude.v13i3.19118

27. Sultana M, Mahumud RA, Sarker AR, Hossain SM. Hand hygiene knowledge and practice among university students: evidence from private universities of Bangladesh. Risk Manag Healthc Policy. 2016;9:13-20. doi: 10.2147/RMHP.S98311

28. Islam MS, Luby SP, Sultana R, Rimi NA, Zaman RU, Uddin M, et al. Family caregivers in public tertiary care hospitals in Bangladesh: risks and opportunities for infection control. Am J Infect Control. 2014;42(3):305-10. doi: 10.1016/j.ajic.2013.09.012

29. Friedrich MN, Julian TR, Kappler A, Nhiwatiwa T, Mosler HJ. Handwashing, but how? Microbial effectiveness of existing handwashing practices in high-density suburbs of Harare, Zimbabwe. Am J Infect Control. 2017;45(3):228-33. doi: 10.1016/j.ajic.2016.06.035

30. Sande-Meijide M, Lorenzo-González M, Mori-Gamarra, F, Cortés-Gago I, González-Vázquez A, Moure-Rodríguez L, et al. Perceptions and attitudes of patients and health care workers toward patient empowerment in promoting hand hygiene. Am J Infect Control. 2018;47(1):4550. doi: 10.1016/j.ajic.2018.07.002 
31. Wang CH, Li JF, Huang LY, Lin FM, Yang YS, Siu LK, et al. Outbreak of imipenem-resistant Acinetobacter baumannii in different wards at a regional hospital related to untrained bedside caregivers. Am J Infect Control. 2017;45(10):1086-90. doi: 10.1016/j.ajic.2017.04.016

32. Bert F, Giacomelli S, Ceresetti D, Zotti CM. World Health Organization framework: multimodal hand hygiene strategy in Piedmont (Italy) health care facilities. J Patient Saf. 2016. doi: 10.1097/PTS.0000000000000352

33. Associação Brasileira de Transplante de Órgãos (ABTO). Registro Brasileiro de Transplantes. Dimensionamento dos transplantes no Brasil e em cada estado (2010-2017) [Internet]. São Paulo: ABTO; 2017 [cited 2019 Mar 14]. Available from: http://www.abto.org.br/abtov03/Upload/ file/RBT/2017/rbt-imprensa-leitura-compressed.pdf 